\title{
THE POLITICAL AND ECONOMIC RESULTS OF APRIL 2013
}

\author{
S.Zhavoronkov
}

In April 2013, rumors of the RF Government's impending sacking suddenly became much more than simply rumors after Vladimir Putin had announced that this option was now on the table. He made that statement at a government meeting at Elista, and the corresponding footage of the event was then 'unofficially' displayed on the LifeNews information portal. It should be said that for some time the government had clearly been confused and dismayed by the ongoing decline in Russia's economic growth. Moreover, the government had repeatedly caused the ire of Igor Sechin, Putin's personal favorite and head of Rosneft, whose attempts to influence the solution of all personnel issues and to create for Rosneft some unprecedented benefits and uniquely favorable conditions had been rebuffed by a number of ministers. All those factors had apparently increased the government's vulnerability. In April, the Russian authorities received considerable diplomatic assistance from US President Barack Obama, who refrained from including in the Magnitsky List any more or less important Russian officials. Obama's 'moderation' was interpreted in Moscow as a green light to further onslaught on non-profit organizations and their across-the-board labeling as 'foreign agents'.

In April 2013, rumors of the RF Government's impending sacking suddenly became much more than simply rumors. Russia's state-owned and state-controlled TV channels displayed a lot of critical materials concerning the government in general, and Vice Prime Minister Arcady Dvorkovich in particular. It is especially noteworthy that, on the eve of Prime Minister Dmitry Medevedev's report to Parliament on 17 April, the FSB-affiliated LifeNews portal displayed a video footage of Vladimir Putin's speech at a government meeting in Elista. It should be added that this news portal had never before published any materials compromising the authorities: all its disclosures had been concerned with the Opposition only. In particular, Vladimir Putin said: "...How are we working? The quality of work is negligible. All surfactants do. If we are going to work like that then we'll achieve nothing ... It must be done! If we do not, it will be necessary to admit that either I do not work effectively, or you are running bad and you need to go! I draw your attention to the fact that to date, I am leaning towards the second option! I think that's understandable. In order not to have any illusions'. When asked about the authenticity of the video footage, Putin's press secretary Dmitry Peskov confirmed its veracity, but said that Putin's outburst had been addressed to a meeting of governors (formally devoted to the state of affairs in the housing and utilities sector). Yet another affront to Dmitry Medvedev came from Speaker of the State Duma Sergey Naryshkin, who insisted that Medvedev's protégé, RF Minister of Education Dmitry Livanov, should be dismissed.

The issue of the RF Government's future was also repeatedly raised in the course of Vladimir Putin's Q\&A live TV session on 25 April. It should be said that his answers were far from reassuring for the government. When asked whether he was satisfied with the measures being taken by the government in order to fend off a possible crisis, the President remarked: 'But there have not yet been any special measures'. Then the President was asked whether he thought that in its current composition the Cabinet was actually capable of fully performing its duties. The answer was rather oblique: ' ... Dear friends and colleagues, I share your view that the expectations of all levels of authorities must be high. However, I would draw your attention to the fact that the Government has not yet been working for a year, no year has yet passed ... People have not yet worked for a year. Of course no small amount of grievances have accumulated during that time, but the Cabinet should be allowed enough time to produce results or come to understand that some of its members are unable to ensure such results. That is not something that can be seen in a year. The responsibilities and work of the Government are immense. Again, there may be many complaints, but I don't think that there should be hasty reshuffling since it will do more harm than good'. 
In fact, the criticism of the Government's performance can be divided into three sets of complaints. Set one (these complaints are wholeheartedly shared by the Government's opponents): the Government does not have any strictly defined concept of Russia's socio-economic development; it merely responds to emerging problems while trying to postpone any reforms - be it the pension issue, the situation in the military field, or anything equally important. The Prime Minister, who is capable of changing his opinion on crucial issues twice a week (for example, on the issue of replacing VAT by a sales tax) and calling for the creation of offshore zones in the Far East, does not produce an impression of being the main driving force of any change, either. Given the sharp drop in Russia's economic growth at the beginning of 2013, a government that goes with the flow can no longer be tolerated. For the sake of justice, however, it should be admitted that, quite frequently, the Government's evident indecision is merely an upshot of Putin's own indecision - for example, with regard to the pension-reform issue mentioned earlier.

The second (and probably the most important) set of complaints addressed to the Government has to do with the stable anti-Sechin coalition that has emerged within its ranks, to resolutely oppose the limitless ambitions of the head of Rosneft - Putin's favorite for many years. Although it is usually claimed that the anti-Sechin coalition is led by Vice Prime Minister Arcady Dvorkovich, others may affirm, with equal justification, that this group is headed by Minister of Finance Anton Siluanov, Minister of Energy Alexander Novak, or Vice Prime Minister Igor Shuvalov. The Government has every reason to be puzzled about Igor Sechin's perpetual ability to put forth candidates for all government positions and important posts in state-owned companies, and also about Rosneft's privilege to function outside of the market - through its being exempt from paying dividends to the State, its having been granted tax and custom duty benefits by the State, as well as numerous loans and credits from state-owned banks, and its having been granted the monopoly right to develop Russia's continental shelf - while still being unable to boast of any success worth mentioning.

The third (and rather weak) set of complaints is designed to provide a political substation for the second set. Dmitry Medevedev's Government is accused of supporting the Opposition - on the basis of some conspiracy theories coupled with an arbitrary interpretation of some non-important facts (such as, for example, the payment to opposition leader Ilya Ponomarev of a large fee at the Skolkovo Foundation; or the cooperation between the RF Ministry of Education and the wellknown scholar-cum-opposition figure Mikhail Gelfand).

Be what it may, in April 2013 Dmitry Medvedev's Government was actually given the 'black spot'. Putin repeatedly and in various forms let it be understood that the Cabinet's dismissal was a distinct possibility.

As far as Dmitry Medvedev's report to Parliament is concerned, it can only be added that the report contained nothing of special interest. The Prime Minister did not declare his program, but simply tried to fend off numerous rebukes by resorting to such standard (self-) justifications as 'corruption is a state of mind', and also by reminding that the situation in European countries is even worse than in Russia (it may be argued that this generalization is too wide - for example, the growth rates of GDP in Sweden and Estonia are higher than that in Russia; and, moreover, their base levels are incomparable with Russia's), and that Russia is a victim of the worldwide trends (which, by the way, do not prevent some other oil producers like Saudi Arabia or Iraq from having an annual growth rate of 7 to $9 \%$ ).

In his Q\&A live TV session on 25 April, RF President Vladimir Putin looked much more robust than his Prime Minister. Intended as a line of communication with ordinary citizens, the TV session also comprised a number of not-so-ordinary citizens, including former RF Minister of Finance Aleksey Kudrin and Russia's top TV presenter Mikhail Leontiev. Referring to the Sochi meeting on economic issues, Putin said that it had not been 'a meeting of despair': '... We met to assess the situation once again, to listen to each other, to listen to different opinions, to understand our own share of responsibility in this recession. ... Some members of the Government believe that we have significantly contributed to it. Others do not believe this, and think that the downturn is solely a result of negative developments in the global economy.... This dispute is not between the Presidential Executive Office and the Government, but rather within the entire community involved in governing our country. ... The dividing line concerns fundamental issues, particularly the issue of how to re- 
spond to current events'. A number of persons asked Putin whether or not it would be advisable to initiate criminal proceedings against Anatoly Chubais, Anatoly Serdiukov, and some other former and current officials for the embezzlements committed at the institutions and departments subordinate to them. To such questions, Putin gave a detailed and lengthy answer, saying that 'we do not need to go back to the dark period of 1937', that only a court had the right to determine whether or not a person was guilty, and that an administrative mistake was by no means synonymous with crime if the person guilty of that mistake had not actually derived any personal profit from it. When asked whether or not it was advisable to introduce a visa regime with 'backward' countries, Putin slightly reinterpreted the question and began to explain that very soon foreigners would be able to enter Russia only on foreign travel passports, which of course would not represent any barrier to the movement of people. When the editor-in-chief of the independent radio station Echo of Moscow, Aleksey Venediktov asked Putin about political repressions in Russia, the latter naturally denied their existence, including in the case of Aleksey Navalny, who had been charged with 'forcing' the director of a state unitary enterprise to conclude a transaction that was unprofitable for that enterprise (so far, the only proof of the charge being only the director's own deposition): '... If you fight corruption, you have to be squeaky clean yourself, otherwise it can all turn into just self-promotion and political advertizing. Everyone has to be equal before the law-this is the point I want to stress. No one should be under any illusion that just because they spend their time shouting 'stop thief!' they can get away with theft themselves'. As far as the Opposition is concerned, Putin mentioned the recent liberalization of Russia's legislation on political parties and noted that the Opposition was no longer prevented from taking part in elections. As regards the strange draft law banning US adoptions of Russian children (a matter of no concern to the US elite), Putin placed the responsibility for the introduction of that bill into the State Duma upon the MPs who had done this 'on their own initiative'.

In April, Alexander Kiselev was dismissed as Director General of the Russian Post federal state unitary enterprise. He was replaced by ex-businessman Dmitry Strashnov. Russian Post's performance had long been scandalously low, with mail delivery sometimes delayed for months - in spite of the fact that it had never been starved of resources. For example, this federal state unitary enterprise has a huge network of offices granted to it free of charge by the State. Therefore this personnel decision taken by the RF Ministry of Communications can only be applauded.

In April, the state-owned VTB Bank announced the purchase, for $\$ 2.4 \mathrm{bn}$, of Tele2 Russia telecommunications operator. This cheapest mobile telecommunications operator, long denied a license to function in Moscow Oblast, will most likely be resold to one of the 'Big Three' of mobile telecommunications operators - a deal that is expected to drastically reduce competition. This transaction can be regarded as the most definite proof that, despite all the talk about the sales of minority blocks of shares in state-owned companies, the actual policy of the authorities is aimed at increasing, and not reducing, the state sector.

On 12 April 2013, the United States published the so-called Magnitsky List. In accordance with the law passed in late 2012, this list had to include both the persons responsible for the death of the Hermitage Foundation's lawyer Sergei Magnitsky and the theft of Rb 5.4bn from Russia's budget, and the persons guilty of human rights violations in Russia. Many Russian opposition figures had been pinning much hope on that list, justly believing that confiscation of such persons' assets in US territory and a ban on their entry into the USA would be a serious warning to the Russian elite as a whole. However, their hopes have been dashed - Barack Obama's list includes only some rankand-file officials involved in the 'Magnitsky case' and two Chechens accused of committing crimes outside of Russia in the interests of Chechen President Ramzan Kadyrov. Neither Alexander Bastrykin nor Ramzan Kadyrov, nor any of the other odious top-ranking officials - including former RF Deputy Minister of Internal Affairs Aleksey Anichin and Deputy Prosecutor General Viktor Grin, who had directly participated in the "Magnitsky case' - were included in the Magnitsky List. In fact, it looks like President Barack Obama has chosen to openly support Vladimir Putin (despite the fact that such a toothless list can certainly create some problems for himself, because both US political parties had been in favor of the adoption of the Magnitsky List).

Barack Obama's position immediately reflected on Russia's internal policy: shortly after the USA had published the far-too-short Magnitsky List, Russian prosecutors began an across-the 
board investigation of the activities of non-governmental organizations, purportedly designed to establish whether or not they were functioning as 'foreign agents'. The law that made it mandatory for the organizations engaged in political activities (interpreted by the Law extremely widely - as any activities 'aimed at changing Russia's policies') and funded from foreign sources to register as 'foreign agents had come into force on 20 November 2012, thus effectively having been dormant for nearly five months. In April, the 'Foreign Agent' Law finally targeted its first victims - the Association in Defense of Voters' Rights Golos [Voice], which had caused the ire of the authorities by its thorough monitoring of the recent elections, and numerous regional nonprofit organizations -including even the social non-profit organization whose aim is to provide assistance to victims of mucoviscidosis, a grave hereditary disease otherwise known as cystic fibrosis. However, in technical terms, the recipients of foreign funding may still continue their activities - because, in fact, the fee for the registration of a new organization to replace the one that has been closed is reasonably low. 